\title{
Novel copper complexes that inhibit the proteasome and trigger apoptosis in triple-negative breast cancer cells
}

Dong-Dong Li ${ }^{1 *}$, Ernesto Yagüe ${ }^{3}$, Lu-Yao Wang ${ }^{1}$, Lin-Lin Dai ${ }^{1}$, Zi-Bo Yang ${ }^{1}$, Shuang Zhi ${ }^{1}$, Na Zhang $^{1}$, Xiu-Mei Zhao ${ }^{1 *}$, Yun-Hui $\mathrm{Hu}^{2 *}$

${ }^{1}$ Tianjin Institute of Medical and Pharmaceutical Sciences, Tianjin 300020, China

${ }^{2}$ The Third Department of Breast Cancer, Tianjin Medical University Cancer Institute and Hospital, Tianjin 300060

${ }^{3}$ Cancer Research Center, Division of Cancer, Faculty of Medicine, Imperial College London, Hammersmith Hospital Campus, London W12 0NN, UK

*Dong-Dong Li, Tianjin Institute of Medical and Pharmaceutical Sciences, E-mail address: lidongdong2010@163.com;

${ }^{*}$ Xiu-Mei Zhao, Tianjin Institute of Medical and Pharmaceutical Sciences, E-mail address:

zxmmlg@163.com;

*Yun-Hui Hu, The Third Department of Breast Cancer, Tianjin Medical University Cancer Institute and Hospital, E-mail: yunhuihu200408@163.com. 
Table of contents

Experimental

Table 1S

Table 2S

Figure 1S

Table 3S

Table 4S

Table 5S

Table 6S

Figure 2S
Instrumentation, Materials, Synthesis of ligand and complexes 1-5, X-ray crystallography and characterization of complexes 1-5, Biological activity evaluation, and Molecular docking

Crystallographic data and structure refinement parameters for complexes

\section{1-5}

Selected bond lengths $(\AA)$ and angles $\left({ }^{\circ}\right)$ for the complexes 1-5

Cellular morphological changes of MDA-MB-231 and CAL-51 cells treated with $\mathbf{3}$ and $\mathbf{5}$ for $24 \mathrm{~h}$

The CI values of complexes $\mathbf{3}, \mathbf{5}$ in combination with CBP in MDA-MB-231 cells

The CI values of complexes $\mathbf{3}, \mathbf{5}$ in combination with CBP in CAL-51 cells Complexes $\mathbf{3}$ and $\mathbf{5}$ affecting reduce the percentage of MDA-MB-231 cells expressing CSC markers

Complexes 3 and $\mathbf{5}$ affecting reduce the percentage of CAL-51 cells expressing CSC marker ALDH.

Complexes $\mathbf{3}$ and $\mathbf{5}$ abolish tumor forming capacity of TNBC cells in vitro. MDA-MB-231 and CAL-51 cells were planted into CSCs medium to form secondary spheres, and then treated without or with $\mathrm{CBP}, \mathbf{3}$ and $\mathbf{5}$ respectively at indicated concentrations for $72 \mathrm{~h}$. 


\section{Experimental}

\section{Instrumentation}

Elemental analyses for $\mathrm{C}, \mathrm{H}$ and $\mathrm{N}$ were obtained on a Perkin-Elmer analyzer model 240. Infrared spectroscopy on $\mathrm{KBr}$ pellets was performed on a Bruker Vector 22 FT-IR spectrophotometer in the $4000-400 \mathrm{~cm}^{-1}$ regions. ${ }^{1} \mathrm{H}-\mathrm{NMR}$ and ${ }^{13} \mathrm{C}-\mathrm{NMR}$ data were measured at $20{ }^{\circ} \mathrm{C}$ on Bruker Advance $400(400 \mathrm{MHz})$ spectrometer with dimethyl sulfoxide (DMSO) as solvent and tetramethylsilane (TMS) as an internal standard. Mass spectra were obtained from a Shimadzu LCMS-8040 LCMS (ESI). The optical density was measured at the $570 \mathrm{~nm}$ wavelength on a multimode reader (Tecan infinite M200). The fluorescence intensity was measured with a flow cytometer (BD FACSCanto II; BD Biosciences).

\section{Materials}

All the chemicals reagents used in the experiments were of analytical grade and obtained from Tianjin Chemical Reagent Co., Ltd. 4-hydroxybenzaldehyde and 4-chlorobenzaldehyde were purchased from Aladdin. DMSO and 3-(4,5-dimethylthiazol-2-yl)-2,5-diphenyl-tetrazolium bromide (MTT) were purchased from Sigma-Aldrich. The purified human 20S proteasome was from ENZO, and the fluorogenic peptide substrate Suc-LLVY-AMC (for the CT-activity assay) was purchased from AnaSpec Inc. Mouse monoclonal antibodies against Bax (1:2000, \#5023S), Bcl-2 (1:2000,\#15071S) and Caspase-3 (1:1000,\#9662s) as well as rabbit monoclonal antibodies against cleaved-PARP (1:2000, \#5625S) and GAPDH (1:2000, \#5174S) were from Cell Signaling Technology. Rabbit polyclonal antibody against Ub (1:1000, \#YT5498) was from Immunoway. All secondary antibodies were purchased from Cell Signaling Technology. A panel of cell lines derived from human breast tumors (MDA-MB-231, CAL-51, and MCF-7) were obtained from Tianjin Institute of Medical and Pharmaceutical Sciences and Tianjin Medical University Cancer Institute and Hospital. Cells were grown in RPMI-1640 medium supplemented with 10\% fetal bovine serum under standard cell culture conditions ${ }^{1}$.

\section{Synthesis of ligand and complexes}

\section{Synthesis of ligand OH-PIP}

Phenthroline-5,6-dione (4.8 mmol, $1.0 \mathrm{~g})$, 4-hydroxybenzaldehyde (6.8 mmol, $0.8 \mathrm{~g}$ ), $\mathrm{NH}_{4} \mathrm{Ac}$ $(100 \mathrm{mmol})$ and glacial acetic acid $(35 \mathrm{~mL})$ were refluxed for $5 \mathrm{~h}$. The cooled solution was diluted with $35 \mathrm{~mL}$ water and neutralized with concentrated aqueous ammonia. The precipitate was 
washed with water $(20 \mathrm{~mL})$ and a yellow powder was obtained. The precipitate was collected and purified by column chromatography on silica gel (60-100 mesh) with ethanol as eluent to produce the compound as a light yellow powder. Yield: $1.07 \mathrm{~g}, 71 \%$. Elemental analysis: calculated for $\mathrm{C}_{19} \mathrm{H}_{12} \mathrm{~N}_{4} \mathrm{O}$ (312.3) (\%): C,73.06; H, 3.87; N, 17.93. Found (\%): C, 73.04; H, 3.90; N,17.91; IR $\left(\mathrm{KBr}, \mathrm{v}, \mathrm{cm}^{-1}\right): 3383,2362,1828,1612,1483,1400,1355,1278,1180,1072,1030,960,837,738$ 690, 516; ${ }^{1} \mathrm{H}$ NMR (400 MHz, DMSO) $\delta 9.03(\mathrm{dd}, J=4.3,1.7 \mathrm{~Hz}, 2 \mathrm{H}), 8.91(\mathrm{~d}, J=8.1 \mathrm{~Hz}, 2 \mathrm{H})$, $8.13(\mathrm{~d}, J=8.7 \mathrm{~Hz}, 2 \mathrm{H}), 7.83(\mathrm{~s}, 2 \mathrm{H}), 6.99(\mathrm{~d}, J=8.7 \mathrm{~Hz}, 2 \mathrm{H}) ;{ }^{13} \mathrm{C}$ NMR $(400 \mathrm{MHz}, \mathrm{DMSO}) \delta$ 159.45, 151.67, 148.03, 129.96, 128.44, 123.67, 121.58, 116.25; ESI-MS for $\mathrm{C}_{19} \mathrm{H}_{12} \mathrm{~N}_{4} \mathrm{O}:[\mathrm{M}+\mathrm{H}]^{+}$, calculated, m/z 313.3; found, 313.2. [M-H]', calculated, m/z 311.3; found, 311.2.

\section{Synthesis of [Cu(OH-PIP)(Phe)Cl] (1)}

A mixture of Phe $(0.1 \mathrm{mmol}, 18.0 \mathrm{mg})$ and $\mathrm{NaOH}(0.1 \mathrm{mmol})$ in $5 \mathrm{~mL}$ water was added to an aqueous solution of $5 \mathrm{~mL} \mathrm{CuCl} 2 \cdot 2 \mathrm{H}_{2} \mathrm{O}(0.1 \mathrm{mmol}, 17.0 \mathrm{mg})$ with stirring for $30 \mathrm{~min}$ followed by addition of OH-PIP $(0.1 \mathrm{mmol}, 312.5 \mathrm{mg})$ taken in $10 \mathrm{~mL}$ of methanol. The solution was refluxed for $5 \mathrm{~h}$, cooled and filtered. Several days later, green block crystals of $\mathbf{1}$ suitable for X-ray structure analysis were obtained by slow evaporation of the filtrate, collected by filtration, washed with diethyl ether and dried in air. Yield 37\% (based on the copper salts). Elemental analysis data: calculated (\%) for $\mathrm{C}_{28} \mathrm{H}_{23} \mathrm{ClCuN}_{5} \mathrm{O}_{3}$ (576.51): C, 58.33; H, 4.02; N, 12.15. Found (\%): C, 58.35; H, 4.05; N, 12.13. IR (KBr, v, cm-1): 3589, 3128, 2354, 1611, 1526, 1484, 1454, 1404, 1363, 1280 , 1241, 1177, 1136, 1078, 844, 809, 757.

\section{Synthesis of $\left[\mathrm{Cu}(\mathrm{OH}-\mathrm{PIP})(\mathrm{Gly})\left(\mathrm{H}_{2} \mathrm{O}\right)\right] \mathrm{NO}_{3} \cdot 2 \mathrm{H}_{2} \mathrm{O}(2)$}

A mixture of Gly $(0.1 \mathrm{mmol}, 7.5 \mathrm{mg})$ and $\mathrm{NaOH}(0.1 \mathrm{mmol})$ in $5 \mathrm{~mL}$ water was added to an aqueous solution of $5 \mathrm{~mL} \mathrm{Cu}\left(\mathrm{NO}_{3}\right)_{2} \cdot 3 \mathrm{H}_{2} \mathrm{O}(0.1 \mathrm{mmol}, 19.0 \mathrm{mg})$ with stirring for $30 \mathrm{~min}$ followed by addition of OH-PIP $(0.1 \mathrm{mmol}, 312.5 \mathrm{mg})$ taken in $10 \mathrm{~mL}$ of methanol. The solution was refluxed for $5 \mathrm{~h}$, cooled and filtered. Several days later, green block crystals of $\mathbf{2}$ suitable for X-ray structure analysis were obtained by slow evaporation of the filtrate, collected by filtration, washed with diethyl ether and dried in air. Yield 39\% (based on the copper salts). Elemental analysis data: calculated (\%) for $\mathrm{C}_{42} \mathrm{H}_{48} \mathrm{Cu}_{2} \mathrm{~N}_{12} \mathrm{O}_{18}$ (1136.02): C, 44.44; H, 4.26; N, 14.81. Found (\%): C, 44.42; H, 4.28; N, 14.80. IR (KBr, v, cm-1): 3134, 1610, 1524, 1482, 1457, 1385, 1296, 1230, 1175, 1137, 1079, 1039, 957, 848, 814, 742 .

\section{Synthesis of $[\mathrm{Cu}(\mathrm{OH}-\mathrm{PIP})(\mathrm{Ala}) \mathrm{Cl}] \cdot \mathrm{H}_{2} \mathrm{O}$ (3)}

A mixture of Ala $(0.1 \mathrm{mmol}, 9.0 \mathrm{mg})$ and $\mathrm{NaOH}(0.1 \mathrm{mmol})$ in $5 \mathrm{~mL}$ water was added to an 
aqueous solution of $5 \mathrm{~mL} \mathrm{CuCl} 2 \cdot 2 \mathrm{H}_{2} \mathrm{O}(0.1 \mathrm{mmol}, 17.0 \mathrm{mg})$ with stirring for $30 \mathrm{~min}$ followed by addition of OH-PIP $(0.1 \mathrm{mmol})$ taken in $10 \mathrm{~mL}$ of methanol. The solution was refluxed for $5 \mathrm{~h}$, cooled and filtered. Several days later, green block crystals of $\mathbf{3}$ suitable for X-ray structure analysis were obtained by slow evaporation of the filtrate, collected by filtration, washed with diethyl ether and dried in air. Yield 36\% (based on the copper salts). Elemental analysis data: calculated (\%) for $\mathrm{C}_{44} \mathrm{H}_{40} \mathrm{Cl}_{2} \mathrm{Cu}_{2} \mathrm{~N}_{10} \mathrm{O}_{7}$ (1018.86): C, 51.87; H, 3.96; N, 13.75. Found (\%): C, 51.90; H, 3.98; N, 13.73. IR ( $\left.\mathrm{KBr}, v, \mathrm{~cm}^{-1}\right): 3418,3068,1612,1526,1483,1457,1406,1362$, $1278,1246,1179,1114,1078,851,814,741$.

\section{Synthesis of $[\mathrm{Cu}(\mathrm{OH}-\mathrm{PIP})(\mathrm{Met})]\left(\mathrm{PF}_{6}\right) \cdot 2 \mathrm{H}_{2} \mathrm{O}(4)$}

A mixture of Met $(0.1 \mathrm{mmol}, 15.0 \mathrm{mg})$ and $\mathrm{NaOH}(0.1 \mathrm{mmol})$ in $5 \mathrm{~mL}$ water was added to an aqueous solution of $5 \mathrm{~mL} \mathrm{Cu}\left(\mathrm{NO}_{3}\right)_{2} \cdot 3 \mathrm{H}_{2} \mathrm{O}(0.1 \mathrm{mmol}, 19.0 \mathrm{mg})$ with stirring for $30 \mathrm{~min}$ followed by addition of OH-PIP $(0.1 \mathrm{mmol})$ taken in $10 \mathrm{~mL}$ of methanol. The solution was refluxed for $3 \mathrm{~h}$, then $\mathrm{NH}_{4} \mathrm{PF}_{6}(0.1 \mathrm{mmol})$ was added and refluxed for further $2 \mathrm{~h}$, cooled and filtered. Several days later, green block crystals of $\mathbf{4}$ suitable for X-ray structure analysis were obtained by slow evaporation of the filtrate, collected by filtration, washed with diethyl ether and dried in air. Yield $39 \%$ (based on the copper salts). Elemental analysis data: calculated (\%) for $\mathrm{C}_{24} \mathrm{H}_{24} \mathrm{CuF}_{6} \mathrm{~N}_{5} \mathrm{O}_{5} \mathrm{P} \mathrm{S}$ (703.06): C, 41.02; H, 3.44; N, 9.97. Found (\%): C, 41.01; H, 3.46; N,9.95. IR (KBr, v, $\left.\mathrm{cm}^{-1}\right)$ : $3343,3136,2918,2362,1604,1526,1483,1458,1407,1365,1269,1227,1173,1079,1051,852$, 740.

\section{Synthesis of $\left[\mathrm{Cu}(\mathrm{OH}-\mathrm{PIP})(\mathrm{Gln})\left(\mathrm{H}_{2} \mathrm{O}\right)\right] \mathrm{Cl} \cdot 3 \mathrm{H}_{2} \mathrm{O}(5)$}

A mixture of Gln $(0.1 \mathrm{mmol}, 15.0 \mathrm{mg})$ and $\mathrm{NaOH}(0.1 \mathrm{mmol})$ in $5 \mathrm{~mL}$ water was added to an aqueous solution of $5 \mathrm{~mL} \mathrm{CuCl} 2 \cdot 2 \mathrm{H}_{2} \mathrm{O}(0.1 \mathrm{mmol}, 17.0 \mathrm{mg})$ with stirring for $30 \mathrm{~min}$ followed by addition of OH-PIP $(0.1 \mathrm{mmol}, 312.5 \mathrm{mg})$ taken in $10 \mathrm{~mL}$ of methanol. The solution was refluxed for $5 \mathrm{~h}$, cooled and filtered. Several days later, green block crystals of 5 suitable for X-ray structure analysis were obtained by slow evaporation of the filtrate, collected by filtration, washed with diethyl ether and dried in air. Yield 37\% (based on the copper salts). Elemental analysis data: calculated (\%) for $\mathrm{C}_{24} \mathrm{H}_{30} \mathrm{ClCuN}_{6} \mathrm{O}_{8}$ (629.53): $\mathrm{C}, 45.79 ; \mathrm{H}, 4.80 ; \mathrm{N}, 13.35$. Found (\%): $\mathrm{C}, 45.83$; H, 4.84; N, 13.32. IR (KBr, v, cm-1): 3209, 1670, 1639, 1611, 1527, 1484, 1458, 1386, 1342, 1280 , $1182,1129,1101,1078,1052,851$.

\section{X-ray crystallography}


A single crystal of each of the complexes 1-5 was used for X-ray diffraction analyses by mounting it on the tip of a glass fiber in air. Crystal data were collected at 113(2) or 293(2) or 386(2) K, using a Bruker SMART CCD 1000 diffractometer. Diffraction intensities for the complexes were collected by using the $\omega$-scan technique. The structures were solved by direct methods using the program SHELXS-97 and subsequent Fourier difference techniques, and refined anisotropically by full-matrix least-squares on $F^{2}$ using SHELXL-97. All the nonhydrogen atoms were refined anisotropically and all the hydrogen atoms were located in the Fourier difference maps. Further crystallographic data and experimental details for structural analyses of complexes 1-5 are summarized in Table 1S. Selected bond angles and distances are listed in Table 2S. CCDC reference numbers for the complexes 1-5 are 1566785, 1566786, 1566787, 1566788 and 1566789 , respectively.

Complex 1 is composed of a [Cu (OH-PIP)(Phe)Cl] unit; the copper atom is five-coordinated with two nitrogen atoms from OH-PIP, one oxygen and nitrogen atoms from Phe and one chlorine atom from copper salt. The trigonality $\tau$ value was calculated to be 0.10 according to the Addison-Reedijk geometric criterion, (where $\tau=(\beta-\alpha) / 60$, with $\alpha$ and $\beta$ being the two largest coordination angles around the metal center. For ideal square-pyramidal geometry $\tau=0$, while for perfect trigonal-bipyramidal geometry $\tau=1$ the geometry can be described as a square-pyramidal configuration). $\mathrm{N}(1), \mathrm{N}(2), \mathrm{N}(3)$ and $\mathrm{O}(2)$ atoms consist of the equatorial plane with $\mathrm{Cu}(1)-\mathrm{N}(1)$ 2.002(6), $\mathrm{Cu}(1)-\mathrm{N}(2)$ 2.033(6), $\mathrm{Cu}(1)-\mathrm{N}(3)$ 2.005(6) and $\mathrm{Cu}(1)-\mathrm{O}(2)$ 1.948(5) $\AA$, respectively. $\mathrm{Cl}(1)$ atom occupies apical position with $\mathrm{Cu}(1)-\mathrm{Cl}(1) 2.552$ (2) $\AA$. The deviations of the four donor atoms from their mean plane are $0.0526,0.0521,0.0571$, and $0.0452 \AA$, respectively. The copper atom is $0.2815 \AA$ out of the basic planar. Complex 2 is composed of a $\left[\mathrm{Cu}(\mathrm{OH}-\mathrm{PIP})(\mathrm{Gly})\left(\mathrm{H}_{2} \mathrm{O}\right)\right]^{+}$ cation, a $\mathrm{NO}_{3}{ }^{-}$anion and two water molecules. Copper atom is five-coordinated with two nitrogen atoms from OH-PIP, one oxygen and nitrogen atoms from Gly, and one oxygen from water. The trigonality $\tau$ value was calculated to be 0.02 according to the Addison-Reedijk geometric criterion, the geometry can be described as a square-pyramidal configuration. $\mathrm{N}(1), \mathrm{N}(2), \mathrm{N}(3)$ and $\mathrm{O}(1)$ atoms consist of the equatorial plane with $\mathrm{Cu}(1)-\mathrm{N}(1) 2.000(6), \mathrm{Cu}(1)-\mathrm{N}(2) 2.006(5), \mathrm{Cu}(1)-\mathrm{N}(3)$ 2.001(5) and $\mathrm{Cu}(1)-\mathrm{O}(1)$ 1.954(4) $\AA$, respectively. $\mathrm{O}(3)$ atom occupies apical position with $\mathrm{Cu}(1)-\mathrm{O}(3) 2.260(7) \AA$. The deviations of the four donor atoms from their mean plane are 0.0354 , $0.0164,0.0183$, and $0.0174 \AA$, respectively. The copper atom is $0.1589 \AA$ out of the basic planar. 
Complex 3 is composed of a $[\mathrm{Cu}(\mathrm{OH}-\mathrm{PIP})(\mathrm{Ala})(\mathrm{Cl})]$ unit. Copper atom is five-coordinated with two nitrogen atoms from OH-PIP, one oxygen and nitrogen atoms from Gly, and one chlorine atom from copper salt. The trigonality $\tau$ value was calculated to be 0.08 according to the Addison-Reedijk geometric criterion, the geometry can be described as a square-pyramidal configuration. $\mathrm{N}(1), \mathrm{N}(2), \mathrm{N}(3)$ and $\mathrm{O}(1)$ atoms consist of the equatorial plane with $\mathrm{Cu}(1)-\mathrm{N}(1)$ 1.989(5), $\mathrm{Cu}(1)-\mathrm{N}(2)$ 2.022(5), $\mathrm{Cu}(1)-\mathrm{N}(3)$ 1.991(5) and $\mathrm{Cu}(1)-\mathrm{O}(1)$ 1.936(4) $\AA$, respectively. $\mathrm{Cl}(1)$ atom occupies apical position with $\mathrm{Cu}(1)-\mathrm{Cl}(1) 2.6974(17) \AA$. The deviations of the four donor atoms from their mean plane are $0.0749,0.0501,0.0557$, and $0.0562 \AA$, respectively. The copper atom is $0.1609 \AA$ out of the basic planar. Complex 4 is composed of a [Cu(OH-PIP)(Met) $]^{+}$ cation, a $\mathrm{PF}_{6}{ }^{-}$anion and two water molecules. Copper atom is five-coordinated with two nitrogen atoms from OH-PIP, one oxygen and nitrogen atoms from Met, and one oxygen atom from another Met. The trigonality $\tau$ value was calculated to be 0.003 according to the Addison-Reedijk geometric criterion, the geometry can be described as a square-pyramidal configuration. N(1), $\mathrm{N}(2), \mathrm{N}(5)$ and $\mathrm{O}(2)$ atoms consist of the equatorial plane with $\mathrm{Cu}(1)-\mathrm{N}(1)$ 1.990(6), $\mathrm{Cu}(1)-\mathrm{N}(2)$ 2.000(6), $\mathrm{Cu}(1)-\mathrm{N}(5)$ 1.998(6)and $\mathrm{Cu}(1)-\mathrm{O}(2)$ 1.937(5) $\AA$, respectively. $\mathrm{O}(1)$ atom occupies apical position with $\mathrm{Cu}(1)-\mathrm{O}(1) 2.424(5) \AA$. The deviations of the four donor atoms from their mean plane are $0.0083,0.0078,0.0113$, and $0.0082 \AA$, respectively. The copper atom is $0.1056 \AA$ out of the basic planar. Complex 5 is composed of a $\left[\mathrm{Cu}(\mathrm{OH}-\mathrm{PIP})(\mathrm{Gln})\left(\mathrm{H}_{2} \mathrm{O}\right)\right]^{+}$cation, a chlorine anion and three water molecules. Copper atom is five-coordinated with two nitrogen atoms from $\mathrm{OH}-\mathrm{PIP}$, one oxygen and nitrogen atoms from Gly, and one oxygen from water. The trigonality $\tau$ value was calculated to be 0.08 according to the Addison-Reedijk geometric criterion, the geometry can be described as a square-pyramidal configuration. $\mathrm{N}(1), \mathrm{N}(2), \mathrm{N}(5)$ and $\mathrm{O}(2)$ atoms consist of the equatorial plane with $\mathrm{Cu}(1)-\mathrm{N}(1)$ 2.025(4), $\mathrm{Cu}(1)-\mathrm{N}(2)$ 1.986(4), $\mathrm{Cu}(1)-\mathrm{N}(5)$ 1.989(4) and $\mathrm{Cu}(1)-\mathrm{O}(2) 1.952(4) \AA$, respectively. $\mathrm{O}(5)$ atom occupies apical position with $\mathrm{Cu}(1)-$ $\mathrm{O}(5) 2.338(4) \AA$. The deviations of the four donor atoms from their mean plane are $0.0813,0.1153$, 0.1032 , and $0.0759 \AA$, respectively. The copper atom is $0.0708 \AA$ out of the basic planar.

\section{Biological activity evaluation}

\section{Cell viability analysis}

The effect of the prepared compounds on a panel of cancer cells was measured by a viability assay. Log-phase growing cells were diluted to $2 \times 10^{4}$ cells $/ \mathrm{mL}$ with complete medium and 
$100 \mu \mathrm{L}$ of the cell suspension was added to each well of 96-well culture plates. The subsequent incubation was performed for $24 \mathrm{~h}$ at $37{ }^{\circ} \mathrm{C}$ under a $5 \% \mathrm{CO}_{2}$ atmosphere prior to the cytotoxicity assessments. The tested samples at preset concentrations were added to wells. After a $72 \mathrm{~h}$ exposure period, $40 \mu \mathrm{L}$ PBS containing $2.5 \mathrm{mg} \cdot \mathrm{mL}^{-1}$ MTT was added to each well for $4 \mathrm{~h}$. Due to cellular metabolic activity, MTT is reduced to its insoluble formazan. The media with MTT were removed, and $150 \mu \mathrm{L}$ DMSO was added to dissolve formazan crystals at room temperature. The absorbance of each cell was measured at $570 \mathrm{~nm}$ using a multimode reader (Tecan infinite M200), being an excellent surrogate for cell viability ${ }^{2}$. All experiments were performed in triplicate, and the percentage of cell inhibitory effect was calculated according to the following equation: Inhibition rate $(\%)=1-\left[\mathrm{A}_{570}(\right.$ sample $) / \mathrm{A}_{570}($ control $\left.)\right] \times 100 \%$

where $\mathrm{A}_{570}$ (sample) refers to the reading from the wells treated with compounds and $\mathrm{A}_{570}$ (control) refers to that from the wells treated with medium containing 10\% PBS only. The level of cytotoxicity is indicated as the $\mathrm{IC}_{50}$ value, which is the concentration of drug that inhibits cell survival by $50 \%$.

\section{Determination of synergy}

CAL-51 and MDA-MB-231 cells were seeded in triplicate in 96-well plates and allowed to recover overnight. The cells were then treated for $72 \mathrm{~h}$ with combination of different concentration of complexes and a fixed concentration of carboplatin (CBP). Cell viability assays were performed as above and the combination index (CI) was determined according to the method of Ting-Chao Chou and Nick Martin using CompuSyn software ${ }^{3}$. CI value lower than 1.0 was considered evidence of synergism.

\section{$20 S$ proteasome inhibiton assay}

The effect of the complex on $20 \mathrm{~S}$ proteasome activity was determined essentially as described ${ }^{4}$. Briefly, $0.1 \mu \mathrm{g}$ of purified 20S human proteasome was incubated with $6.25 \mu \mathrm{g} \cdot \mathrm{mL}^{-1}$ fluorogenic substrate Suc-LLVY-AMC, specific for the CT-like activity, for $2 \mathrm{~h}$ at $37{ }^{\circ} \mathrm{C}$ in $200 \mu \mathrm{L}$ of assay buffer (50 mM Tris-HCl, $\mathrm{pH} 7.5$ ) with different concentrations of sample. After incubation, the production of hydrolyzed AMC groups was measured using a multimode reader (Tecan infinite M200) with an excitation filter of $380 \mathrm{~nm}$ and an emission filter of $440 \mathrm{~nm}$. The changes in fluorescence were calculated against the DMSO-treated control. 
Morphological changes in the cancer cells after indicated treatments were observed using a Zeiss (Thornwood, NY) Axiovert 25 microscope with phase contrast. For cell apoptosis analysis, an Annexin V-fluorescein isothiocyanate (FITC) and propidium iodide (PI) double-staining apoptosis detection kit (BD Biosciences) were used according to the procedure suggested by the manufacturer. In total, $2 \times 10^{5}$ cells were washed twice with PBS and suspended in $100 \mu \mathrm{L}$ binding buffer, followed by staining with $5 \mu \mathrm{L}$ Annexin V-FITC and $5 \mu \mathrm{L}$ PI for $15 \mathrm{~min}$ in the dark at room temperature. The fluorescence intensity was measured using a flow cytometer (BD FACSCanto II; BD Biosciences) and the average percentage of Annexin V-positive cells was used as a measure of apoptosis, both in the early (Annexin V-positive and PI-negative) and late (Annexin V-positive and PI-positive) stages of apoptosis.

\section{Protein extraction and western blotting}

MDA-MB-231 and CAL-51 cells were seeded in 6-well plates and treated with different concentrations of copper complexes for $24 \mathrm{~h}$. After treatment, cells were washed twice with PBS and lysed in Triton-X 100 lysis buffer $(50 \mathrm{mM}$ Tris- $\mathrm{HCl}, 150 \mathrm{mM} \mathrm{NaCl}, 1 \%$ Triton-X 100, $0.25 \%$ SDS, $0.25 \%$ sodium deoxycholate, $1 \mathrm{mM}$ EDTA, $1 \mathrm{mM}$ ethylene glycol-bis( $\beta$-aminoethyl ether)-N,N,N',N'-tetraacetic acid and $1 \mathrm{mM}$ dithiothreitol) containing protease inhibitors (EMD Millipore, Billerica, MA, USA) to isolate proteins from whole cells. The protein concentration of each sample was determined using a bicinchoninic acid protein assay (Peirce; Thermo Fisher Scientific, Inc.). The samples were separated by SDS-PAGE, transferred to PVDF membranes (Millipore, Bedford, MA, USA) by electroblotting, and probed with antibodies against Caspase-3, Bax, Bcl-2, PARP, Ub and GAPDH following standard procedures 5 . The membranes were incubated with $\lg$ G secondary antibody conjugated with alkaline phosphatase, followed by detection with ECL reagent (Millipore Bedford, MA, USA) and visualization on autoradiography film.

\section{Mammosphere forming assay}

Single cells were plated at 10000 cells $/ \mathrm{mL}$ on 6-well plates in serum-free DMEM/F12 supplemented with $20 \mathrm{ng} \cdot \mathrm{mL}^{-1} \mathrm{EGF}, 4 \mathrm{mg} \cdot \mathrm{mL}^{-1}$ insulin, $5 \mu \mathrm{g} \cdot \mathrm{mL}^{-1}$ heparin (Sigma-Aldrich), 1 $\mu \mathrm{g} \cdot \mathrm{mL}^{-1}$ hydrocortisone, 0.5\% BSA (Sigma-Aldrich) and B27 (Sigma-Aldrich). Fresh medium was supplemented every three days.

MDA-MB-231 and CAL-51 cells were suspended into CSCs permissive medium for seven days 
to allow spherogenesis, then spheres were disaggregated and equal number single cells were replanted for five days. Subsequently, secondary spheres were replanted into medium without or with CBP, $\mathbf{3}$ and $\mathbf{5}$ for $72 \mathrm{~h}$ and their morphology monitored by microscopy.

\section{Fluorescence activated cell sorting analyses (FACS)}

For stem cell marker analysis, APC-conjugated CD44 and phycoerythrin (PE)-conjugated CD24 monoclonal antibodies (BD Biosciences, San Jose, CA, USA) were used essentially as described ${ }^{6}$. Cells were resuspended in PBS at $1 \times 10^{6}$ cells $/ \mathrm{mL}$ and both APC-CD44 and PE-CD24 antibodies, or their respective isotype controls APC-IgG and PE-IgG, added and incubated for $40 \mathrm{~min}$ at $4^{\circ} \mathrm{C}$ in the dark. Labeled cells were washed in PBS and then analyzed in a flow cytometer. Gating was set to relevant isotype control (APC-IgG and PE-IgG)-labeled cells for each cell line.

An Aldefluor assay kit (StemCell Technologies, Vancouver, BC, Canada) was used for the determination of ALDH activity by flow cytometry essentially as described ${ }^{5}$. Briefly, cells were harvested and suspended in Aldefluor assay buffer at $1 \times 10^{6}$ cells $/ \mathrm{mL}$. As a negative control, half the sample was transferred to a tube containing $5 \mu \mathrm{L}$ of ALDH inhibitor diethylaminobenzaldehyde. Activated Aldefluor substrate $(5 \mu \mathrm{L})$ was added to both samples and incubated at $37{ }^{\circ} \mathrm{C}$ for $45 \mathrm{~min}$ to allow substrate conversion. Cells were then resuspended in Aldefluor assay buffer and analyzed using a flow cytometer.

\section{Molecular docking}

The basis of molecular docking is that receptor and ligand recognize and interact with each other by hydrogen bonding and a variety of electrostatic, hydrophobic and van der Waals interactions. The chemical structures of the complexes were built with ChemOffice and their energy minimized using Open Babel before conversion to a PDBQT file with AutoDockTools (ADT) for further docking. The crystal structure of proteasome (PBD ID: 3MG6) was obtained from the RCSB Protein Data Bank. With the aid of $\mathrm{ADT}^{7}$, water molecules in the complexes were deleted, hydrogen atoms were added to the protein and then saved as a PDBQT file. For the active site, a grid box with parameters obtained from Pymol was centered at the ligand LZT. After docking all conformations of flexible ligand with Lamarckian Genetic Algorithm (LGA) using AutoDock $4.2^{8}$, the estimated free energy of binding and inhibition constant were used as criteria for the evaluation of results. 
Table 1S Crystallographic data and structure refinement parameters for complexes 1-5

\begin{tabular}{|c|c|c|c|c|c|}
\hline Complex & 1 & 2 & 3 & 4 & 5 \\
\hline \multirow[t]{2}{*}{ Empirical formula } & $\mathrm{C}_{28} \mathrm{H}_{23} \mathrm{ClCuN}_{5} \mathrm{O}_{3}$ & $\mathrm{C}_{42} \mathrm{H}_{48} \mathrm{Cu}_{2} \mathrm{~N}_{12} \mathrm{O}_{18}$ & $\mathrm{C}_{44} \mathrm{H}_{40} \mathrm{Cl}_{2} \mathrm{Cu}_{2} \mathrm{~N}_{10}$ & $\mathrm{C}_{24} \mathrm{H}_{24} \mathrm{CuF}_{6} \mathrm{~N}_{5} \mathrm{O}_{5} \mathrm{P}$ & $\mathrm{C}_{24} \mathrm{H}_{30} \mathrm{ClCuN}_{6} \mathrm{O}_{8}$ \\
\hline & & & $\mathrm{O}_{7}$ & $\mathrm{~S}$ & \\
\hline Formula weight & 576.51 & 1136.02 & 1018.86 & 703.06 & 629.53 \\
\hline Crystal system & orthorhombic & Triclinic & Triclinic & monoclinic & monoclinic \\
\hline Space group & $\mathrm{P} 2{ }_{1} 2{ }_{1} 2$ & $\mathrm{P}-1$ & $\mathrm{P}-1$ & $\mathrm{C} 12 / \mathrm{c} 1$ & $\mathrm{P} 21 / \mathrm{c}$ \\
\hline$a / \AA$ & $27.8460(13)$ & $12.0406(10)$ & $12.4816(8)$ & $28.681(4)$ & $7.882(2)$ \\
\hline$b / \AA$ & $4.1231(4)$ & $13.5668(18)$ & $13.1691(9)$ & $6.9371(8)$ & $30.306(7)$ \\
\hline$c / \AA$ & $13.2530(10)$ & $16.8939(15)$ & $16.8231(13)$ & $28.223(4)$ & $10.957(3)$ \\
\hline$\alpha / \circ$ & 90.00 & $74.112(9)$ & $82.402(6)$ & 90.00 & 90.00 \\
\hline$\beta / \circ$ & 90.00 & $70.602(8)$ & $75.485(6)$ & $104.930(3)$ & $95.958(7)$ \\
\hline$\gamma / \circ$ & 90.00 & $72.277(9)$ & $69.805(5)$ & 90.00 & 90.00 \\
\hline$V / \AA^{3}$ & 2997.8(3) & $2433.2(4)$ & $2509.2(3)$ & $5425.7(12)$ & $2603.2(12)$ \\
\hline$Z, D_{c} / \mathrm{mg} \mathrm{m}^{-3}$ & $2,1.277$ & $2,1.551$ & $2,1.349$ & $8,1.721$ & $4,1.606$ \\
\hline$\mu / \mathrm{mm}^{-1}$ & 0.853 & 0.961 & 1.010 & 1.030 & 1.003 \\
\hline$F(000)$ & 1184 & 1734 & 1044 & 2856 & 1304 \\
\hline Reflections collected & 20019 & 20827 & 28041 & 31232 & 24689 \\
\hline Unique reflections & 5471 & 9916 & 9091 & 4442 & 5270 \\
\hline$R_{\text {int }}$ & 0.0650 & 0.0453 & 0.0504 & 0.0632 & 0.0735 \\
\hline Goodness-of-fiton $\mathrm{F}^{2}$ & 1.202 & 1.035 & 1.074 & 1.249 & 1.296 \\
\hline$R_{1} / w R_{2}[I>2 \sigma(I)]$ & $0.0755 / 0.2056$ & $0.0814 / 0.2322$ & $0.0751 / 0.1968$ & $0.0873 / 0.2061$ & $0.0704 / 0.1498$ \\
\hline$R_{1} / w R_{2}$ (all data) & 0.0998 / 0.2694 & $0.1264 / 0.2785$ & $0.0855 / 0.2033$ & $0.1083 / 0.2147$ & $0.0843 / 0.1545$ \\
\hline$\triangle \rho(\max . / \min .) / \mathrm{e} \AA^{-3}$ & $0.001 / 0.000$ & $0.050 / 0.045$ & $0.001 / 0.000$ & $0.003 / 0.000$ & $0.001 / 0.000$ \\
\hline
\end{tabular}


Table 2S Selected bond lengths $(\AA)$ and angles $\left(^{\circ}\right)$ for the complexes 1-5

\begin{tabular}{|c|c|c|c|c|c|c|c|}
\hline \multicolumn{8}{|l|}{ Complex 1} \\
\hline $\mathrm{Cu}(1)-\mathrm{Cl}(1)$ & $2.551(3)$ & $\mathrm{Cu}(1)-\mathrm{O}(2)$ & $1.951(6)$ & $\mathrm{Cu}(1)-\mathrm{N}(1)$ & $1.997(7)$ & $\mathrm{Cu}(1)-\mathrm{N}(2)$ & $2.039(7)$ \\
\hline $\mathrm{Cu}(1)-\mathrm{N}(3)$ & $2.009(7)$ & & & & & & \\
\hline $\mathrm{O}(2)-\mathrm{Cu}(1)-$ & $99.62(19)$ & $\mathrm{O}(2)-\mathrm{Cu}(1)-$ & $83.0(3)$ & $\mathrm{O}(2)-\mathrm{Cu}(1)-$ & $160.3(3)$ & $\mathrm{O}(2)-\mathrm{Cu}(1)-$ & $91.3(3)$ \\
\hline $\mathrm{Cl}(1)$ & & $\mathrm{N}(1)$ & & $\mathrm{N}(2)$ & & $\mathrm{N}(3)$ & \\
\hline $\mathrm{N}(1)-\mathrm{Cu}(1)-$ & $95.4(2)$ & $\mathrm{N}(1)-\mathrm{Cu}(1)-$ & $99.7(3)$ & $\mathrm{N}(1)-\mathrm{Cu}(1)-$ & $166.5(3)$ & $\mathrm{N}(2)-\mathrm{Cu}(1)-$ & $99.6(2)$ \\
\hline $\mathrm{Cl}(1)$ & & $\mathrm{N}(2)$ & & $\mathrm{N}(3)$ & & $\mathrm{Cl}(1)$ & \\
\hline $\mathrm{N}(3)-\mathrm{Cu}(1)-$ & $97.7(2)$ & $\mathrm{N}(2)-\mathrm{Cu}(1)-$ & $81.7(3)$ & & & & \\
\hline $\mathrm{Cl}(1)$ & & $\mathrm{N}(3)$ & & & & & \\
\hline \multicolumn{8}{|l|}{ Complex 2} \\
\hline $\mathrm{Cu}(1)-\mathrm{O}(1)$ & $1.954(4)$ & $\mathrm{Cu}(1)-\mathrm{N}(3)$ & $2.001(5)$ & $\mathrm{Cu}(1)-\mathrm{N}(1)$ & $2.000(6)$ & $\mathrm{Cu}(1)-\mathrm{N}(2)$ & $2.006(5)$ \\
\hline $\mathrm{Cu}(1)-\mathrm{O}(3)$ & $2.260(7)$ & & & & & & \\
\hline $\mathrm{O}(1)-\mathrm{Cu}(1)-$ & $92.52(19)$ & $\mathrm{O}(1)-\mathrm{Cu}(1)-$ & $84.1(2)$ & $\mathrm{N}(3)-\mathrm{Cu}(1)-$ & 169.1(3) & $\mathrm{O}(1)-\mathrm{Cu}(1)-$ & $170.5(2)$ \\
\hline $\mathrm{N}(3)$ & & $\mathrm{N}(1)$ & & $\mathrm{N}(1)$ & & $\mathrm{N}(2)$ & \\
\hline $\begin{array}{l}\mathrm{N}(3)-\mathrm{Cu}(1)- \\
\mathrm{N}(2)\end{array}$ & $82.0(2)$ & $\begin{array}{l}\mathrm{N}(2)-\mathrm{Cu}(1)- \\
\mathrm{N}(1)\end{array}$ & $99.8(2)$ & $\begin{array}{l}\mathrm{O}(1)-\mathrm{Cu}(1)- \\
\mathrm{O}(3)\end{array}$ & $95.6(2)$ & $\begin{array}{l}\mathrm{O}(3)-\mathrm{Cu}(1)- \\
\mathrm{O}(3)\end{array}$ & $96.4(2)$ \\
\hline $\begin{array}{l}\mathrm{N}(1)-\mathrm{Cu}(1)- \\
\mathrm{O}(3)\end{array}$ & $94.3(3)$ & $\begin{array}{l}\mathrm{N}(2)-\mathrm{Cu}(1)- \\
\mathrm{O}(3)\end{array}$ & $92.8(2)$ & & & & \\
\hline \multicolumn{8}{|l|}{ Complex 3} \\
\hline $\mathrm{Cu}(1)-\mathrm{N}(1)$ & $1.992(7)$ & $\mathrm{Cu}(1)-\mathrm{N}(2)$ & $2.019(7)$ & $\mathrm{Cu}(1)-\mathrm{N}(3)$ & $1.987(7)$ & $\mathrm{Cu}(1)-\mathrm{O}(1)$ & $1.938(6)$ \\
\hline $\mathrm{Cu}(1)-\mathrm{Cl}(1)$ & $2.698(2)$ & & & & & & \\
\hline $\begin{array}{l}\mathrm{N}(1)-\mathrm{Cu}(1)- \\
\mathrm{Cl}(1)\end{array}$ & $96.9(3)$ & $\begin{array}{l}\mathrm{N}(1)-\mathrm{Cu}(1)- \\
\mathrm{N}(2)\end{array}$ & $102.0(3)$ & $\begin{array}{l}\mathrm{N}(2)-\mathrm{Cu}(1)- \\
\mathrm{Cl}(1)\end{array}$ & $90.4(2)$ & $\begin{array}{l}\mathrm{N}(3)-\mathrm{Cu}(1)- \\
\mathrm{Cl}(1)\end{array}$ & $96.5(2)$ \\
\hline $\begin{array}{l}\mathrm{N}(1)-\mathrm{Cu}(1)- \\
\mathrm{N}(3)\end{array}$ & $166.1(3)$ & $\begin{array}{l}\mathrm{N}(2)-\mathrm{Cu}(1)- \\
\mathrm{N}(3)\end{array}$ & $81.8(3)$ & $\begin{array}{l}\mathrm{O}(1)-\mathrm{Cu}(1)- \\
\mathrm{Cl}(1)\end{array}$ & $96.0(2)$ & $\begin{array}{l}\mathrm{O}(1)-\mathrm{Cu}(1)- \\
\mathrm{N}(1)\end{array}$ & $83.6(3)$ \\
\hline $\begin{array}{l}\mathrm{O}(1)-\mathrm{Cu}(1)- \\
\mathrm{N}(2)\end{array}$ & $171.0(3)$ & $\begin{array}{l}\mathrm{O}(1)-\mathrm{Cu}(1)- \\
\mathrm{N}(3)\end{array}$ & $91.1(3)$ & & & & \\
\hline \multicolumn{8}{|l|}{ Complex 4} \\
\hline $\mathrm{Cu}(1)-\mathrm{O}(1)$ & $2.424(5)$ & $\mathrm{Cu}(1)-\mathrm{O}(2)$ & $1.937(5)$ & $\mathrm{Cu}(1)-\mathrm{N}(1)$ & $1.990(6)$ & $\mathrm{Cu}(1)-\mathrm{N}(2)$ & $2.000(6)$ \\
\hline $\mathrm{Cu}(1)-\mathrm{N}(5)$ & $1.998(6)$ & & & & & & \\
\hline $\begin{array}{l}\mathrm{O}(1)-\mathrm{Cu}(1)- \\
\mathrm{O}(2)\end{array}$ & $90.8(2)$ & $\begin{array}{l}\mathrm{O}(2)-\mathrm{Cu}(1)- \\
\mathrm{N}(1)\end{array}$ & $92.8(2)$ & $\begin{array}{l}\mathrm{O}(2)-\mathrm{Cu}(1)- \\
\mathrm{N}(2)\end{array}$ & $172.8(2)$ & $\begin{array}{l}\mathrm{O}(2)-\mathrm{Cu}(1)- \\
\mathrm{N}(5)\end{array}$ & $84.5(2)$ \\
\hline $\begin{array}{l}\mathrm{O}(1)-\mathrm{Cu}(1)- \\
\mathrm{N}(1)\end{array}$ & $87.7(2)$ & $\begin{array}{l}\mathrm{N}(2)-\mathrm{Cu}(1)- \\
\mathrm{N}(1)\end{array}$ & $82.4(2)$ & $\begin{array}{l}\mathrm{N}(5)-\mathrm{Cu}(1)- \\
\mathrm{N}(1)\end{array}$ & $173.0(3)$ & $\begin{array}{l}\mathrm{O}(1)-\mathrm{Cu}(1)- \\
\mathrm{N}(2)\end{array}$ & $94.4(2)$ \\
\hline $\begin{array}{l}\mathrm{O}(1)-\mathrm{Cu}(1)- \\
\mathrm{N}(5)\end{array}$ & $98.8(2)$ & $\begin{array}{l}\mathrm{N}(2)-\mathrm{Cu}(1)- \\
\mathrm{N}(5)\end{array}$ & $99.6(2)$ & & & & \\
\hline \multicolumn{8}{|l|}{ Complex 5} \\
\hline $\mathrm{Cu}(1)-\mathrm{O}(2)$ & $1.952(4)$ & $\mathrm{Cu}(1)-\mathrm{N}(2)$ & $1.986(4)$ & $\mathrm{Cu}(1)-\mathrm{N}(5)$ & $1.989(4)$ & $\mathrm{Cu}(1)-\mathrm{N}(1)$ & $2.025(4)$ \\
\hline $\mathrm{Cu}(1)-\mathrm{O}(5)$ & $2.338(4)$ & & & & & & \\
\hline $\begin{array}{l}\mathrm{O}(2)-\mathrm{Cu}(1)- \\
\mathrm{N}(2)\end{array}$ & $91.54(16)$ & $\begin{array}{l}\mathrm{O}(2)-\mathrm{Cu}(1)- \\
\mathrm{N}(5)\end{array}$ & $84.51(16)$ & $\begin{array}{l}\mathrm{N}(2)-\mathrm{Cu}(1)- \\
\mathrm{N}(5)\end{array}$ & $168.86(19)$ & $\begin{array}{l}\mathrm{O}(2)-\mathrm{Cu}(1)- \\
\mathrm{N}(1)\end{array}$ & $173.72(16)$ \\
\hline $\mathrm{N}(2)-\mathrm{Cu}(1)-$ & $82.27(17)$ & $\mathrm{N}(5)-\mathrm{Cu}(1)-$ & $101.77(17)$ & $\mathrm{O}(2)-\mathrm{Cu}(1)-$ & $90.39(14)$ & $\mathrm{N}(2)-\mathrm{Cu}(1)-$ & $94.54(16)$ \\
\hline
\end{tabular}




\begin{tabular}{lllll}
$\mathrm{N}(1)$ & $\mathrm{N}(1)$ & $\mathrm{O}(5)$ & $\mathrm{O}(5)$ \\
$\mathrm{N}(5)-\mathrm{Cu}(1)-$ & $95.90(16)$ & $\mathrm{N}(1)-\mathrm{Cu}(1)-$ & $89.07(15)$ & \\
$\mathrm{O}(5)$ & $\mathrm{O}(5)$ & & \\
\hline
\end{tabular}

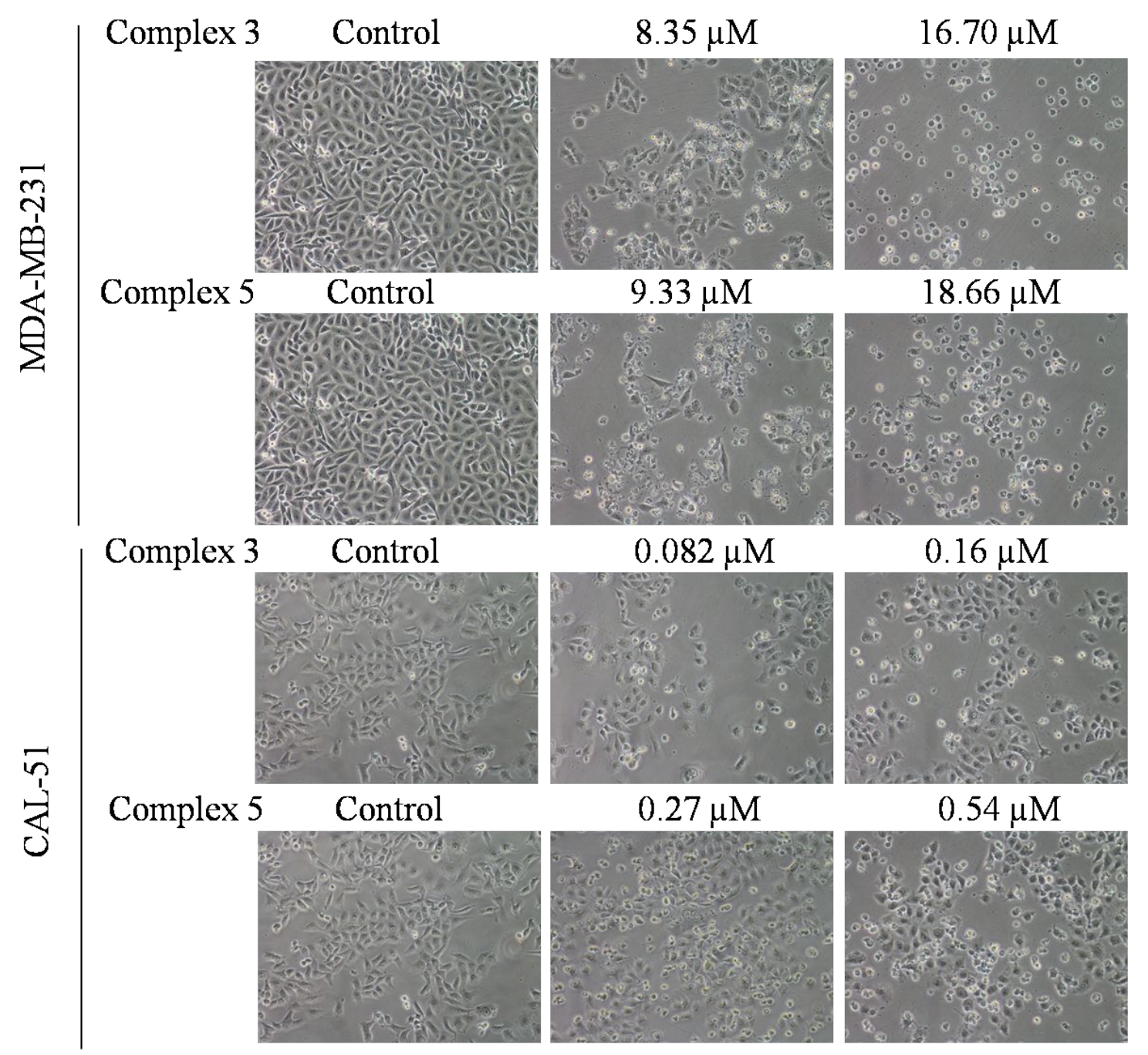

Figure 1S Cellular morphological changes of MDA-MB-231 and CAL-51 cells treated with 3 and 5 for 24 h. 
Table 3S The CI values of complexes $\mathbf{3}$ and $\mathbf{5}$ in combination with CBP in MDA-MB-231 cells

\begin{tabular}{ccccc}
\hline Complex & $\begin{array}{c}\text { Dose of complex } \\
(\mu \mathrm{M})\end{array}$ & $\begin{array}{c}\text { Dose of CBP } \\
(\mu \mathrm{M})\end{array}$ & $\begin{array}{c}\text { Total Inhibition } \\
(\%)\end{array}$ & CI value \\
\hline \multirow{6}{*}{$\mathbf{3}$} & 25.0 & 3.0 & 83.83 & 0.93 \\
& 12.5 & 3.0 & 83.54 & 0.48 \\
& 6.25 & 3.0 & 55.59 & 0.65 \\
& 3.12 & 3.0 & 40.24 & 0.67 \\
& 1.56 & 3.0 & 39.68 & 0.50 \\
& 0.78 & 3.0 & 32.67 & 0.58 \\
& 0.39 & 3.0 & 33.26 & 0.50 \\
\hline & 12.5 & 3.0 & 89.41 & 0.03 \\
& 6.25 & 3.0 & 75.00 & 0.10 \\
& 3.12 & 3.0 & 48.02 & 0.40 \\
& 0.78 & 3.0 & 35.25 & 0.53 \\
& 0.39 & 3.0 & 28.23 & 0.74 \\
& 0.19 & 3.0 & 24.12 & 0.92 \\
\hline
\end{tabular}

Table 4S The CI values of complexes 3 and 5 in combination with CBP in CAL-51 cells

\begin{tabular}{ccccc}
\hline Complex & $\begin{array}{c}\text { Dose of complex } \\
(\mu \mathrm{M})\end{array}$ & $\begin{array}{c}\text { Dose of CBP } \\
(\mu \mathrm{M})\end{array}$ & $\begin{array}{c}\text { Total } \\
\text { Inhibition }(\%)\end{array}$ & CI value \\
\hline \multirow{4}{*}{3} & 6.25 & 0.5 & 72.23 & 0.96 \\
& 3.12 & 0.5 & 65.94 & 0.79 \\
& 1.56 & 0.5 & 68.44 & 0.46 \\
& 0.78 & 0.5 & 66.50 & 0.37 \\
& 0.39 & 0.5 & 56.91 & 0.44 \\
& 0.19 & 0.5 & 42.70 & 0.63 \\
\hline \multirow{3}{*}{$\mathbf{5}$} & 6.25 & 0.5 & 71.70 & 0.86 \\
& 3.12 & 0.5 & 69.49 & 0.59 \\
& 1.56 & 0.5 & 66.33 & 0.46 \\
& 0.78 & 0.5 & 60.86 & 0.43 \\
& 0.39 & 0.5 & 41.21 & 0.74 \\
& 0.19 & 0.5 & 37.46 & 0.73 \\
\hline
\end{tabular}


Table 5S Complexes $\mathbf{3}$ and $\mathbf{5}$ affecting reduce the percentage of MDA-MB-231 cells expressing CSC markers

\begin{tabular}{cccc}
\hline Compound & $\begin{array}{c}\text { Concentration } \\
(\mu \mathrm{M})\end{array}$ & $\begin{array}{c}\text { Ratio of } \\
\text { CD44 } / \text { CD24 }(\%)\end{array}$ & $\begin{array}{c}\text { Ratio of } \\
\text { ALDH1+ }(\%)\end{array}$ \\
\hline Control & - & 94.2 & 22.7 \\
\hline $\mathbf{3}$ & 4.18 & 91.1 & 4.93 \\
& 8.35 & 38.9 & 1.72 \\
$\mathbf{5}$ & 16.70 & 12.3 & 0.72 \\
\hline & 4.66 & 91.4 & 1.92 \\
& 9.33 & 62.0 & 1.14 \\
\hline
\end{tabular}

Table 6S Complexes 3 and $\mathbf{5}$ affecting reduce the percentage of CAL-51 cells expressing CSC marker ALDH.

\begin{tabular}{ccc}
\hline Compound & $\begin{array}{c}\text { Concentration } \\
(\mu \mathrm{M})\end{array}$ & $\begin{array}{c}\text { Ratio of } \\
\text { ALDH1+ }(\%)\end{array}$ \\
\hline Control & - & 45.40 \\
\hline \multirow{3}{*}{0.041} & 19.30 \\
& 0.082 & 12.50 \\
$\mathbf{5}$ & 0.16 & 8.25 \\
\hline & 0.14 & 25.50 \\
& 0.27 & 19.40 \\
\hline
\end{tabular}



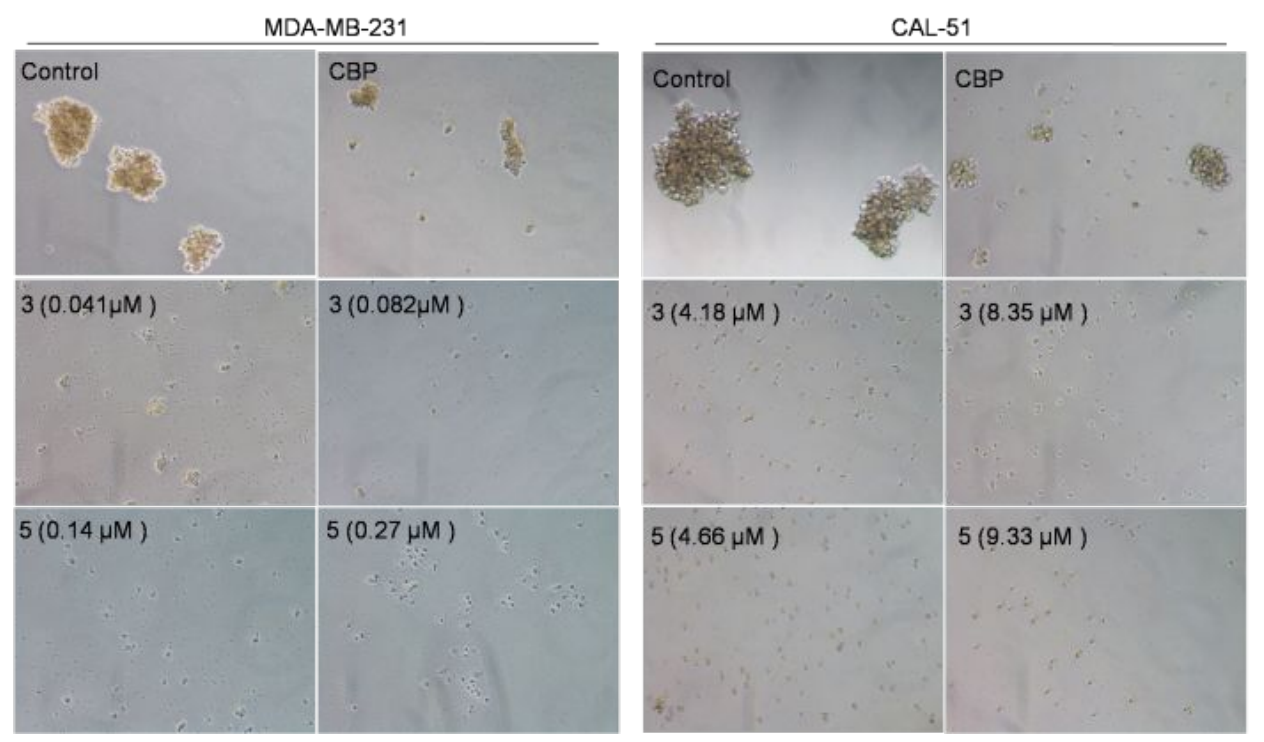

Figure 2S Complexes $\mathbf{3}$ and $\mathbf{5}$ abolish tumor forming capacity of TNBC cells in vitro. MDA-MB-231 and CAL-51 cells were planted into CSCs medium to form secondary spheres, and then treated without or with CBP, 3 and $\mathbf{5}$ respectively at indicated concentrations for $72 \mathrm{~h}$.

\section{Notes and Reference}

1. Hu, Y.; Guo, R.; Wei, J.; Zhou, Y.; Ji, W.; Liu, J.; Zhi, X.; Zhang, J. Effects of PI3K inhibitor NVP-BKM120 on overcoming drug resistance and eliminating cancer stem cells in human breast cancer cells. Cell Death Dis. 2015, 6, e2020.

2. T. Mosmann. Rapid colorimetric assay for cellular growth and survival: application to proliferation and cytotoxicity assays. Journal of Immunological Methods 1983, 65, 55-63.

3. Chou, T. C.; Martin, N. CompuSyn for drug combinations: PC software and user's guide: a computer program for quantitation of synergism and antagonism in drug combinations, and the determination of $\mathrm{IC}_{50}$ and $\mathrm{ED}_{50}$ and $\mathrm{LD}_{50}$ values. ComboSyn, Paramus, $\mathrm{NJ}, 2005$.

4. Chang, J. J.; Shi, W. D.; Hua, Y. Q. A binuclear complex constituted by diethyldithiocarbamate and copper (I) functions as a proteasome activity inhibitor in pancreatic cancer cultures and xenografts. Toxicology and Applied Pharmacology 2013, 273, 477-483.

5. Liu, J. J.; Liu, L.; Yagüe, E.; Yang, Q. X.; Pan, T.; Zhao, H.; Hu, Y. H.; Zhang, J. GGNBP2 suppresses triple-negative breast cancer aggressiveness through inhibition of IL-6/STAT3 
signaling activation. Breast Cancer Res. Treat. 2019, 174, 65-78.

6. Hu, Y.; Yague, E.; Zhao, J.; Wang, L.; Bai, J.; Yang, Q.; Pan, T.; Zhao, H.; Liu, J.; Zhang, J. Sabutoclax, pan-active BCL-2 protein family antagonist, overcomes drug resistance and eliminates cancer stem cells in breast cancer. Cancer Letter 2018, 423, 47-59.

7. Michel, F.; Sanner, M. F. Python: A Programming Language for Software Integration and Development. J. Mol. Graphics Mod. 1999, 17, 57-61.

8. Morris, G. M.; Huey, R.; Lindstrom, W.; Sanner, M. F.; Belew, R. K.; Goodsell, D. S.; Olson, A. J. AutoDock4 and AutoDockTools4: Automated docking with selective receptor flexibility. J. Computational Chemistry 2009, 16, 2785-2791. 